\title{
Europe and its development perspectives.
}

\author{
Closing conference of the Academic Year 2018/2019
}

\author{
Alberto Quadrio-Curzio ${ }^{1,2}$ \\ Published online: 26 February 2020 \\ (c) Accademia Nazionale dei Lincei 2020
}

The theme I am addressing today has been often discussed at the Lincei Academy from numerous angles and at multiple times, given that a number of our Fellows have personally contributed to the construction of Europe. We can count among these the Giants of political thought and institutional relations, Benedetto Croce and Luigi Einaudi, who played a fundamental role in re-founding our Society and are counted among the founding fathers of the Italian Republic. ${ }^{1}$

I wish to start from Luigi Einaudi ${ }^{2}$ since his institutional, social and economic vision for a united Europe has provided to this day important lessons throughout his works, of which we, Lincei Fellows, have always been cognizant and have often revisited.

Today, in the current climate of perilous misperception that has imbued various European nations, we can acquire vision and courage from the lucid wisdom of statesmen who matured their convictions, indeed also from their human suffering, caused by the atrocities of the first half of the twentieth century, and who chose the prospect of a united Europe as the more promising option including for their nation.

Obviously, perspectives for transitioning from the twentieth to the twenty-first century are not merely encapsulated in Einaudi's thought. Thus, our reflections will concentrate on some events that have recently occurred in Europe and on what remains to be implemented to continue down the path of peace and development by which post WWII civil progress has been characterized on our continent.

My conviction as an institutional economist is that the current EU democracy is an admirable but not complete application of the principles of shared and innovative

Alberto Quadrio-Curzio

quadriocurzio@lincei.it; alberto.quadriocurzio@unicatt.it

1 Presidente Emerito, Accademia Nazionale dei Lincei, Via della Lungara 10, 00165 Rome, Italy

2 Professore Emerito di Economia Politica, Università Cattolica di Milano, Milan, Italy subsidiarity through which to obtain the needed social liberalism that constitutes a civil society-led Europe.

\section{Luigi Einaudi and the construction of Europe}

When Einaudi became a Fellow, at 32 years of age in the 1906, he had already started reflecting on and writing about a concept of Europe; this lifelong reflection, only interrupted during fascism, ended with his passing away in 1961. In his impressive train of thought, one can see various phases: functionalism, confederalism and federalism, which contributed to creating that virtuous hybrid which is represented today by EU democracy. Other aspects of Einaudi's reflections, of interest to us here, are:

- The need to move beyond European States'absolute sovereignty and build a greater institutional order with the foremost objective of guaranteeing peace. In his unforgettable July 1947 speech before the Italian Constituent Assembly, Einaudi identified "as the number one enemy of civilization, of prosperity (...) the myth of absolute national sovereignty (...)" and warned that in "a Europe where every pestiferous return to nationalistic myths feeds into suddenly discovered impassioned patriotic currents (...), the work of unification is all the more urgent (...)".3

- The need to break down European national borders and the delimiting economic areas that are too small to fully exploit market potential, competition, economies of scale and scope, as well as innovation.

\footnotetext{
1 The speech was delivered in the presence of the President of the Italian Republic, Sergio Mattarella, on 20 June 2019 at the Accademia Nazionale dei Lincei, Rome.

${ }^{2}$ Luigi Einaudi (1874-1961), Lincei Fellow from 1906, was the second President of the Italian Republic (1948-1955).

${ }^{3}$ For a more comprehensive quotation see the Appendix.
} 
- The need for a single currency in Europe, but also the availability of financial means for managing the Union and its institutions, i.e., democracy, government and defense.

Many of Einaudi's ideas are found in Europe's construction even if one is not always aware of the debt owed him.

\section{Prospects for broadening economic-institutional reforms}

I am naturally aware that the geopolitical and geo-economic changes of the twenty-first century seem radical. Just as it is clear that the recent years of economic crisis have weakened Europe, even if on average the EU's and Economic and Monetary Union's (EMU) GDP between 2014 and 2015 surpassed 2008 levels. Unfortunately, the response to contrast the economic crisis has been slow due to a lack of expanding European economic policies. The salvaging of some countries in great economic crisis found support only in the socalled European Stability Mechanism (ESM), an important innovation which is now seldom used, while in fact it could be implemented for an expansive European economic policy.

Europe, with its ideals and principles, has nonetheless the potential to also become a strong pillar of coexistence among Peoples as long as it stays solidly grounded in the Treaties of Rome signed in March 1957. That date marks the beginning of the construction of democracy, which notwithstanding many difficulties, has continued to grow, from the important (at times forgotten) EU Charter of Fundamental Rights in 2000, to the 60th anniversary of the treaties, when in 2017 the "Declaration of Rome" was signed by the leaders of the member states and by the presidents of the top European institutions. It is a declaration upon which everyone should meditate deeply; it should be introduced not only to students, but also especially to those in positions of responsibility in government.

In the construction of Europe, the mix of ideals, projects and concrete application has almost always operated well in the medium to long term, even if to varying degrees. Sometimes ideals have given strength to concreteness and viceversa. We believe that from here to 2024 (that is, by the end of the IX European legislature) or better yet, to the end of 2027 (which concludes the seven-year cycle of the EU budget which began in 2021), the thrust should go to those projects and programs which unite ideals and concrete application of those projects which have been already approved, or are in the process of being implemented.

Proposals of different types have been elaborated by the European Commission, European Parliament, and the Five Presidents' Committee. Their complexity might not be pleasing to those who forget that real politics, for the common good, is founded upon the knowledge of facts, project competence and actionable ideas with the aim of finding definitive solutions to problems. Especially at the European level, politics requires the convergence of three institutions (European Parliament European Commission and European Council), which results in a certain degree of complexity that cannot be discussed here. We can, however, mention that the economic-institutional proposals have ample areas of convergence, especially regarding deepening and strengthening (open) cooperation in the Eurozone.

While not having the time to go through all of the proposals mentioned above, a few hints will be provided of the Five Presidents' Report (which includes the European Commission, ECB, European Council, Eurogroup, European Parliament); the first report was issued in 2012, the most recent in 2015. It has been discussed multiple times at European summits and has been partially implemented, but progress has not always been noticed since, symbolically speaking, many look at the individual "bricks" that are laid and not at the "house" itself. The Eurogroup of finance ministers has continued to work on a proposal which tomorrow (21 June) should be examined at the European Summit.

In recent years, two members of the Five Presidents' Committee have had extant, albeit different, roles in laying the "bricks" of our twenty-first century European home: Draghi and Juncker. Both have a concept of Europe founded on principles and areas of competence that they have brought to the Five Presidents' Report, which identifies various fronts on which to "deepen" cooperation: strengthen institutions, a budget for integrated policies, an economic union based on convergence and cohesion among the member states, and a more integrated fiscal and banking union. Some of these projects are in the process of being implemented; others should be added, also drawing from the projects developed by the European Parliament (especially concerning policies to contrast shocks) and the European commission (in particular cooperation on industrial projects for cutting-edge technologies).

We know that Draghi has done a great deal more by implementing significant ECB interventions without triggering cracks at the institutional level, thus obtaining two extraordinary and complementary results: on the one hand, saving the Eurozone (and EU) from a critically dire predicament; and on the other hand, proving to its international economic and institutional interlocutors that the ECB is a protagonist and not merely an added actor.

Juncker (who has been often underestimated) has relaxed fiscal compact for those countries intent on implementing reforms and making investments, and presenting a European plan for greater investment financing.

Lastly, Chancellor Merkel has also made significant efforts, notwithstanding her strong critics and internal 
opposition. History will confirm, in my opinion, her noteworthy contribution.

\section{Programs for investing in infrastructure, education and innovation}

Developing complex institutional projects requires time, that is why we should quickly move toward a European program with concrete sectoral investments for intra- and extraEuropean infrastructures, which includes functionalism by Sector of investment, and Confederalism for institutions and financing instruments.

Innovative solidarity and participatory subsidiarity are crucial principles that must underpin these projects.

The European economic and financial crisis from 2007 to 2018 caused a dramatic cumulative drop of gross fixed investments equal to $€ 3300$ billion in the EU27 of which $€ 2900$ billion in the Eurozone alone. These are enormous sums. Europe must absolutely recover from this loss with a grand investment plan.

Regarding intra-European infrastructure, there are various proposals (only a few of which are being implemented) regarding materials (communication and transmission networks), immaterial needs (education and research), social aspects (schools, hospitals, etc. with the recent European project coordinated by Romano Prodi), and cooperation in industrial techno-science for globally competitive companies, like the Airbus consortium. The focus should be on innovation (which combines research and education) and renewing existing environmentally compatible infrastructures to create more global centers of excellence like CERN.

However, these goals require greater financial resources, which could be obtained by issuing Eurobonds. Confederal European bonds were proposed for the first time in 1993 ( 25 years ago!) by Delors and then redrafted in varying forms, by many scholars and recently by the European Parliament and European Commission. I myself developed a variant which I have called EuroUnionBond. These bonds would be issued by a federal Eurozone institution to which member states would provide real guarantees; for example, a share of their gold reserves (which would provide them with greater protection from government hazards) and government-held company shares (which could later favor mergers of large companies in strategic sectors). If every member state of the EMU were to provide an amount, equivalent to its share of GDP in the Eurozone, to a federal European institution that had the capacity to emit bonds, according to our calculations it would be possible to collect as much as $€ 1000$ billion of actual guarantees, on which it could issue bonds, with a leverage of three Eurobonds per $€ 3000$ billion, enabling it to generate a multiplier effect. Over the next 10 years and beyond, the Eurozone, and therefore the entire EU, could renew and strengthen its whole economy as well as its territorial convergence and social cohesion, with greater focus on educating the new generations upon which depends the future of our civil society-led solidarity.

Regarding investments in extra-European infrastructure, Africa represents an absolute priority (and potential) for Europe. From its current population of 1.3 billion, Africa in 2050 will have a population of 2.5 billion with uncontrollable migratory flows, and with all the consequences that are currently visible with a much smaller migratory influx.

The EU does not have an adequate policy for Africa, even if the total of its public funds (EU and individual states combined) for developing countries is the largest in the world, with an annual expenditure of $€ 80$ billion.

These are nonetheless scattered interventions. Why not then use the model proposed by the European Bank for Reconstruction and Development (EBRD) (of which the EU is the main shareholder through the European Investment Bank)? Let us remember that EBRD was founded in 1990 to assist the 12 EU countries, from central Eastern Europe and Central Asia, transition toward market economies. That conundrum, smaller than what we face today in Africa, was tackled with determination and innovation. The EBRD in 2018 provided minimum funding to North African Mediterranean countries; it was not strictly within its area of competence, but with a change in its Mission it could become so, thus allowing it to funnel all of the existing EU and individual member state's aid for development.

The issue of investments now brings us to the role of the European Stability Mechanism (ESM), which is currently being underused, and the role of the European Investment Bank (EIB), founded in 1957 with the Treaty of Rome; which, if its scope were broadened, could be given the mandate to issue Eurobonds for greater intra- and extra-European infrastructure investments. The EIB, co-owned by EU member states, is the largest and most stable multilateral development bank in the world. It finances investments of around $€ 70$ billion annually in innovative infrastructure, environmental compatibility and industries. Approximately, $90 \%$ of its investments go to EU member states; the rest is redistributed among 130 countries which include five North African Mediterranean countries.

The EIB, the ECB, but also the EBRD and the ESM are European institutions, imbued with extraordinary "innovative solidarity", which have enormous systemic potential to increase the weight of the Euro in financial and exchange rate diversification on a global scale with respect to the dollar. 


\section{Conclusion: the European Union and multilateralism}

I began by stating that the twenty-first century will see great change and that European multilateralism, constructed after World War II, risks coming unhinged. Today, at the beginning of the twenty-first century, macro-dynamics are at work. Projections show that in 2050, the world population will have increased to 10 billion and it is expected that new economic powers could take the lead in terms of world GDP shares (in purchasing power parity-PPP), China could lead with $20 \%$, India with $15 \%$; and they would move clearly beyond the USA's share which is expected to decrease to $12 \%$, while the EU's share could decrease to $9 \%$. With these new dynamics, there will surely be a shift in currency assets to the detriment of the United States which has built its strategic supremacy on the US Dollar. For Europe, it is comforting to note that the Euro, which is only 20 years old, is already quite strong.

There are also techno-scientific challenges that, unfortunately, interconnect with an increase in arms spending; while Europe, for an equivalent defense capacity, could easily spend much less by accessing the savings generated from investing in the mentioned intra- and extra-European sectors.

We believe that Europe can provide valuable input in attenuating global risks by contributing to implementing the UN 2030 Agenda for sustainable development goals. Europe has great economic and technical strength as well as social, cultural and civil assets. Some further conditions, however, are needed, three of which are: first, a decrease in populist tendencies in European member states while continuing the virtuous hybrid dynamic of confederalism and functionalism; second, the EU and EMU should have greater foreign political relevance including a unified presence at the UN Security Council; third, the EU and EMU do not aspire to becoming a third, divisive, pillar in a triangle counterpoised by the USA and China, they desire to become a pillar that defends a multipolar system of multilateral agreements and supranational organizations, and where the UN remains the basis for sharing, civil progress and peace. No single member state of the EU or EMU can aspire to such a role due to its size, which is already small today and could be even more so in 2050 .
In conclusion, I hope to have provided an informative, albeit modest, contribution in support of the recommendations presented in one of the Einaudi's "useless sermons" entitled: "First Know, Then Discuss, and Finally, Deliberate" Prediche Inutili, Einaudi, Turin, 1964, pp. 3-14].

\section{Appendix}

Luigi Einaudi, Speech given at the Italian Constituent Assembly, 29 July 1947, CCVIII, pp. 6425-6426, edited various times with the title "War and a United Europe: speech given at the Constituent Assembly of 29 July 1947":

"Thirty years ago, I wrote and repeated in vain, and repeat today, after the terrible experiences suffered, hopefully no longer in vain, that the number one enemy of civilization and prosperity, and today one must add of the very lives of its people, is the myth of absolute state sovereignty [...]. In a Europe where every pestiferous return to nationalistic myths feeds into suddenly discovered impassioned patriotic currents, in those, who till the day before professed internationalization as an ideal; in this Europe, where with every step taken forward, one sees with horror the tendency toward bellicose urges, the work of unification is all the more urgent. I say work and not sermon. It is meaningless to preach peace and unity, when Hannibal is pounding at the door, when the souls of too many Europeans are inflamed by nationalistic passions. It is not enough to preach a United States of Europe and hold parliamentary conferences. What matters is that the members of parliament of these tiny states, that make up a divided Europe, renounce part of their national sovereignty in favor of a Parliament where they are elected and where they directly represent the European people in their entirety without distinction from state to state, and in proportion to the number of inhabitants, and that in the national parliaments the individual states are represented in the same proportion".

[Translation by the Author of this article].

Publisher's Note Springer Nature remains neutral with regard to jurisdictional claims in published maps and institutional affiliations. 